\title{
Hubungan Antara Grit Terhadap Penyesuaian Diri Siswa Boarding School
}

\author{
Raidah Hanifah, Mujidin, Ahmad Muhammad Diponegoro \\ Fakultas Psikologi, Universitas Ahmad Dahlan \\ Hanifahraidah18@gmail.com, Mujidin_zia@yahoo.com, Yatadabbaru@gmail.com
}

\begin{abstract}
The transition period for school change has an impact on students. This study aims to determine the relationship between grit and self-adjustment of students who carry out the boarding school program in the tenth grade in Yogyakarta. Using cluster random sampling technique, this research was conducted at three middle schools in tenth grade students who conducted a boarding school program with a total of 117 students. The measuring instrument in this study used a grit scale and a selfadjustment scale. Data analysis using mement product correlation. The results showed that the coefficient between grit and self-adjustment was 0.316 with a significance level of $0.001(\mathrm{p}<0.01)$. It is concluded that there is a very significant positive relationship between grit and self-adjustment of tenth grade boarding school students in Yogyakarta. So, the higher the grit, the higher the student's adjustment.
\end{abstract}

Keyword: grit, self-adjustment, boarding school

\begin{abstract}
Abstrak
Masa transisi pergantiantian jenjang sekolah memiliki dampak terhadap siswa. Penelitian ini bertujuan untuk mengetahui hubungan antara grit terhadap penyesuaian diri siswa yang melakukan program boarding school pada kelas sepuluh di Yogyakarta. Menggunakan teknik cluster random sampling, penelitian ini dilakukan pada tiga sekolah menengah pada siswa kelas sepuluh yang melakukan program boarding school dengan jumlah 117 siswa. Instrument pengukuran dalam penelitian ini menggunakan skala grit dan skala penyesuaian diri. Analisi data menggunakan korelasi produk mement. Hasil penelitian menunjukkan bahwa koefisien antara grit dengan penyesuaian diri adalah 0,316 dengan tingkat signifikansi $0,001(\mathrm{p}<0,01)$. Disimpulkan bahwa terdapat hubungan positif yang sangat signifikan antara grit terhadap penyesuaian diri siswa boarding school kelas sepuluh di Yogyakarta. Maka, semakin tinggi grit maka semakin tinggi pula penyesuaian diri siswa.
\end{abstract}

Kata kunci: grit, penyesuaian diri, boarding school

\section{Pendahuluan}

Siswa harus menghadapi beberapa transisi sekolah mulai dari taman kanak-kanak, sekolah dasar, sekolah menengah, hingga perguruan tinggi yang pasti akan menemukan tantangan, meskipun bagi banyak siswa transisi ini sukses akan tetapi bagi sebagian orang ada penurunan yang terlihat dalam kesejahteraan psikologis mereka seperti gejala internalisasi dan eksternalisasi, dan penurunan dalam kompetensi akademik [1]. Sistem boarding school dari sisi sosial mengisolasi anak didik dari lingkungan heterogen yang cenderung buruk. Lingkungan sekolah dan asrama dikonstruksi menjadi suatu lingkungan sosial yang relatif homogen dan satu tujuan yaitu menimba ilmu untuk menggapai harapan hidup yang lebih berkualitas [2]. Kehidupan di asrama tentu berbeda dengan kehidupan sebelumnya ketika masih tinggal di rumah, individu yang memiliki penyesuaian diri yang rendah dan terbiasa dituruti keinginan-keinginannya akan sulit menerima situasi yang berbeda dengan kondisi yang diharapkan, seperti menu makanan yang tidak sesuai dengan seleranya, mandi harus antri, peraturan asrama yang cukup ketat, dan tugas-tugas lain yang cukup banyak. Individu yang terbiasa hidup bebas cenderung sulit untuk disiplin dan mentaati aturan yang ada di asrama, sehingga sering melakukan pelanggaran [3].

Individu yang berhasil melakukan penyesuaian diri akan menghasilkan kepuasan hidup di lingkungan sekolah, menciptakan persepsi sosial yang positif, dan konsep diri akademik yang baik [4] . Penyesuaian diri akan membantu remaja untuk mencapai harmoni pada diri sendiri dan pada lingkungan[5]. Anak-anak yang mengalami penyesuaian diri yang buruk cenderung menghadapi risiko kegagalan akademis, perilaku antisosial, dan menjadi putus sekolah [6]. Kegagalan remaja dalam melakukan penyesuaian diri akan menimbulkan bahaya seperti tidak bertanggung jawab dan mengabaikan pelajaran, sikap agresif, memiliki perasaan tidak aman terhadap sekitar, merasa ingin pulang jika berada jauh dari lingkungan yang tidak dikenal, dan perasaan menyerah [7]. 
Penyesuaian diri secara psikologi didefinisikan sebagai suatu perubahan yang dialami oleh individu untuk mencapai hubungan yang memuaskan dengan orang lain dan lingkungan di sekitarnya [8]. Penyesuaian diri adalah cara individu mengatasi stres dan hambatan-hambatan yang dialami pada kehidupan sehari-hari yang norma, karakteristik penyesuaian diri terdiri dari empat: 1) Goodnes of fit, Perilaku individu harus beradaptasi dengan aturan yang khusus dengan kondisi lingkungan. Kondisi ini dapat bersifat fisik, seperti keadaan geografis lingkungan, sosial, norma dan harapan; 2) Lack of problem, penyesuaian biasanya diasumsikan ketika seseorang tidak mengalami masalah. Kurangnya masalah menunjukkan tingkat keberhasilan dalam berurusan dengan lingkungan. Kurangnya masalah merupakan dampak dari kemampuan mengenali konsekuensi dari tindakan sehingga mampu untuk mengatur perilaku yang sesuai dengan sekitar; 3) Pengalaman hidup yang positif, menikmati pertemanan dengan teman, merasa puas dengan pencapaian beberapa tugas yang sulit, atau menyadari solusi untuk suatu masalah adalah contoh pengalaman hidup yang positif; 4) Integritas kesehatan tubuh dan pikiran, kesehatan pikiran-tubuh akan terjadi jika terjadi integrasi antara pikiran dan tubuh, jika individu tidak berhasil dalam mengatasi stresor tubuh akan menjadi lelah dan rentan terhadap penyakit. Individu yang memiliki kemampuan mengatasi gejala stres dan kecemasan berarti individu mampu mengatasi masalah-masalah yang timbul dalam hidup termasuk mampu menerima kegagalan yang dialami [9].

Siswa yang menginginkan cita-cita jangka panjangnya tercapai harus mampu mempertahankan upaya dan minat yang kuat. Siswa akan mengalami segala macama hambatan dan tantangan dalam perjalanan mencapai tujuannya, maka diperlukan grit. Individu dengan tingkat grit yang lebih tinggi menunjukkan kegigihan yang lebih besar dalam mengejar tujuan mereka meskipun ada kesulitan, kebosanan bahkan kegagalan dibandingkan dengan individu lain yang gritnya kurang, dalam konteks pendidikan grit digambarkan berpengaruh penting pada hasil seperti keterlibatan siswa, tingkat pencapaian, retensi dan probabilitas kelulusan [10].

Pada sampel siswa SMA, kedua dimensi grit terutama ketekunan usaha, berkorelasi positif dengan kepuasan hidup, sifat berhati-hati, perilaku sosial, penyesuaian diri di lingkungan sekolah, tetapi tidak untuk nilai atau kesiapan akademik [11]. Individu dengan grit tingkat tinggi dianggap dapat memanfaatkan kemampuannya dengan lebih baik karena mereka kurang terganggu oleh tujuan jangka pendek dan kurang berkecil hati karena kegagalan dan kemunduran yang biasa ditemui dibanyak domain kinerja [12]. Grit adalah karakter yang dimiliki individu yang ditunjukkan berupa perjuangan keras, kemauan untuk mengambil risiko, sikap hati yang keras, bekerja tanpa henti menuju tujuan, mengambil tantangan dengan tenang, dan memiliki hasrat dan kemauan untuk berprestasi meskipun mengalami kesulitan bahkan jika dalam keadaan yang paling sulit [13]. Grit memiliki dua dimensi, 1) Konsistensi minat, kemampuan untuk mempertahankan minat pada satu tujuan. Individu yang memiliki konsistensi minat biasanya minatnya tidak mudah teralihkan atau berubah-ubah pada setiap waktu maupun keadaaan, individu tersebut tetap mempertahankan minatnya dalam jangka waktu panjang; 2) Ketahanan dalam berusaha, individu tidak takut menghadapi tantangan atau hambatan yang menghalanginya dalam meraih cita-citanya, yaitu tetap bekerja keras dan bersungguh-sungguh untuk mencapai tujuan jangka panjang [14].

\section{Metode Penelitian}

\subsection{Sample Penelitian}

Sampel pada penelitian ini berjumlah 117 subjek laki-laki dan perempuan. Sampel pada penelitian ini adalah siswa sekolah menengah atas yang bersekolah di sekolah $\mathrm{X}$ dan sekolah $\mathrm{Y}$ yang melakukan program asrama di Yogyakarta dengan rentang usia 15-16 tahun.

\subsection{Instrumen Penelitian}

Instrumen pengumpulan data dalam penelitian ini menggunakan model penskalaan likert yang digunakan untuk mengukur sikap, pendapat dan persepsi seseorang atau sekelompok orang tentang fenomena sosial. Skala likert memiliki empat alternatif jawaban yaitu sangat sesuai, sesuai, tidak sesuai dan sangat tidak sesuai. Untuk skor item yang favorabel model skoring yaitu, sangat sesuai $(\mathrm{SS})=4$, sesuai $(\mathrm{S})=3$, tidak sesuai $(\mathrm{TS})=2$, sangat tidak sesuai $(\mathrm{STS})=1$. Sebaliknya untuk item unfavorabel model skoring yaitu, Sangat sesuai $(\mathrm{SS})=1$, sesuai $(\mathrm{S})=2$, Tidak sesuai $=3$ dan sangat tidak sesuai $(\mathrm{STS})=4$. 
Item skala penyesuaian diri mengacu pada karakteristik penyesuaian diri yaitu goodness of fit, lack of problem, pengalaman hidup yang positif, dan inegritas kesehatan tubuh dan pikiran. Jumlah aitem skala penelitian penyesuaian diri yaitu 16 aitem. Contoh aitem dalam skala ini adalah "Setiap mendapatkan hasil yang kurang baik dalam ujian sekolah, akan membuat saya jatuh sakit", "Saya sulit berpakaian sesuai dengan aturan di asrama", "Ketika melanggar aturan, saya sudah siap menerima sanksi". Sementara skala grit mengacu pada dimensi-dimensi grit yaitu, konsistensi minat dan ketahanan dalam berusaha. Jumlah aitem skala grit yaitu 10 aitem. Contoh aitem dalam skala ini adalah "Saya mudah fokus pada tugas-tugas yang membutuhkan waktu lama dalam mengerjakanny", "Minat saya mudah berubah", "Tugas yang sulit membuat saya takut gagal".

2.3 Prosedur and Analisis Data

Prosedur penelitian yang dilakukan terbagi menjadi empat tahap yaitu persiapan, uji coba penelitian, pengumpulan data penelitian dan analisis data. Tahap pertama adalah persiapan, dimulai dengan menyusun instrumen penelitian dan menentukan lokasi penelitian yang sesuai dengan kriteria subjek yang diinginkan. Tahap kedua yaitu uji coba penelitian, dengan menyebarkan skala uji coba kepada 102 orang untuk mengetahui item yang valid. Tahap ketiga adalah pengumpulan data penelitian yaitu menyebarkan skala yang telah direvisi berdasarkan standar validitas dan reliabilitas kepada 117 subjek di lokasi yang ditentukan. Sampel penelitian ditentukan berdasarkan kebutuhan peneliti. Tahap keempat adalah menganalisis data, hasil data yang telah disebarluaskan diberi skoring dan dianalisis dengan asumsi dan uji korelasi produk momen menggunakan perhitungan statistik dibantu dengan aplikasi SPSS versi 21 for windows. Analisis produk momen digunakan untuk mengukur hubungan variabel independen (hardiness) terhadap variabel dependen (penyesuaian diri). Analisis produk momen meliputi uji normalitas, uji linearitas dan uji korelasi.

\section{Hasil dan Pembahasan}

\subsection{Uji Normalitas}

Suatu variabel dikatakan normal jika memiliki skor $\mathrm{p}>0.05$. Berdasarkan data diperoleh skor skala penyesuaian diri adalah 0,224 dan skor dari skala grit adalah 0,103 dapat disimpulkan bahwa sebaran data penelitian adalah normal.

Tabel 1.Uji Normalitas

\begin{tabular}{llll}
\hline Variable & K-SZ Score & Sig. $(\mathrm{p})$ & Keterangan \\
\hline Penyesuaian Diri & 0,224 & $\mathrm{p}>0.05$ & Normal \\
Grit & 0,103 & $\mathrm{p}>0.05$ & Normal \\
\hline
\end{tabular}

\subsection{Uji Linearitas}

Variabel bebas (grit) linear dengan variabel tergantung (penyesuaian diri), jika Sig $\mathrm{F}_{\text {linearity }}$ memiliki skor $p<0.05$ dan sig $F_{\text {deviation from linearity }}$ memiliki skor $p>0,05$. Uji linieritas grit terhadap penyesuaian diri menunjukkan $F_{\text {deviation from linearity }}=1,107$ dengan signifikansi $0,001(p<0,05)$, Ini menunjukkan bahwa variabel-variabel tersebut linier.

Tabel 2.Uji Linearitas

\begin{tabular}{lllll}
\hline Variable & $\mathrm{F}$ & Sig. $(\mathrm{p})$ & Kriteria & Keterangan \\
\hline Penyesuaian diri dan grit & 1,107 & 0,001 & $\mathrm{p}<0,05$ & Linear \\
\hline
\end{tabular}

\subsection{Uji Hipotesis}

Hipotesis diterima jika pearson correlation menunjukkan koefisien korelasi antara dua variabel yang diteliti sig (2-tailed) menunjukkan taraf signifikansi $\mathrm{p}<0,05$ (signifikan) atau $\mathrm{p}<0,01$ (sangat signifikan) dan dinyatakan ditolak jika $p>0,05$. Koefisien korelasi antara grit terhadap penyesuaian diri adalah 0,316 dengan signifikansi 0,001 ( $\mathrm{p}<0,01$ ). Oleh karena itu, secara empiris terbukti terdapat hubungan positif yang sangat signifikan antara grit terhadap penyesuaian diri siswa boarding school.

Tabel 3. Uji Hipotesis

\begin{tabular}{ccccc}
\hline Variable & Pearson-Correlation & Sig. $(\mathrm{p})$ & Kriteria & Keterangan \\
\hline $\begin{array}{c}\text { Grit terhadap } \\
\text { penyesuaian diri }\end{array}$ & 0,316 & 0,001 & $\mathrm{P}<0,01$ & Sangat signifikan \\
\hline
\end{tabular}


Siswa yang mampu membentuk penyesuaian diri yang baik akan mampu bertahan dalam keadaan apapun di lingkungan yang telah dipilihnya demi tercapai tujuan yang diinginkan. Penyesuaian diri yang berhasil dilakukan oleh individu terkait dengan sifat dan kemampuan yang berasal dari dalam diri individu salah satunya yaitu grit, selain itu dukungan sosial dan hubungan individu dengan orangtua juga berpengaruh terhadap kemampuan penyesuaian diri di lingkungan akademik individu [15]. Grit dapat bermanfaat untuk individu yang baru saja memasuki lingkungan pendidikan yang lebih tinggi dari sebelumnya, grit yang dimiliki akan mampu membantu penyesuaian diri di lingkungan akademik maupun di lingkungan sosial di luar kelas [16]. Siswa diharuskan untuk mengorbankan waktunya, tenaga, dan dirinya untuk menghadapi berbagai kesulitan dan tantangan yang ada di lingkungan asrama demi tercapainya tujuan. Ketika siswa memiliki tujuan jangka panjang yang bermakna maka dirinya akan menunjukkan passion (semangat, antusiasme, dan gairah) yang tinggi untuk mecapai goal. Siswa yang mampu memelihara passion tidak akan mudah menyerah saat mengahdapi kesulitan dimanapun.

Penelitian menunjukkan bahwa grit berkontribusi terhadap kemampuan penyesuaian diri pada siswa [17]. Individu yang merantau menunjukkan skor grit yang berbeda dibandingkan dengan kelompok bukan perantau, ditemukan kelompok perantau memiliki skor grit yang lebih tinggi, hal ini menunjukkan bahwa mungkin saja situasi sulit seperti stres ketika melakukan penyesuaian diri yang dihadapi individu yang merantau memberikan tantangan sekaligus kesempatan untuk mengembangkan grit, individu yang mampu melewati kesulitan penyesuaian diri dengan baik, maka grit mereka akan terbentuk sedangkan, pada individu yang bukan perantau dan tinggal di lingkungan yang familiar bagi mereka, kemungkinan mendapatkan sedikit kemudahan yang membuat mereka tidak terdesak untuk berusaha lebih dibanding individu yang merantau[18].

Hasil dari penelitian ini juga menunjukkan kontribusi variabel grit sebesar 9,99\% terhadap penyesuaian diri sisanya dipengaruhi varibel lain yang tidak terindentifikasi dalam penelitian ini. Grit yang dimiliki oleh subjek akan mampu membantu untuk fokus dan tidak mudah goyah pada satu tujuan yang telah dicita-citakann. Pada penelitian yang dilakukan grit mampu memprediksi keterlibatan akademis dan kegagalan akademis[19]. Penelitian lainnya menunjukkan bahwa grit terbukti mampu menjelaskan hasil pendidikan siswa, dampak positif dari siswa yang memiliki grit yang cukup baik menunjukkan prestasi akademik yang memuaskan, siswa dengan skor grit tinggi tidak mudah menyerah dalam menghadapi kesulitan, mampu memahami pentingnya ketekunan dan semangat untuk tujuan jangka panjang [20.].

\section{Kesimpulan}

Salah satu faktor yang mempengaruhi penyesuian diri yaitu grit. Temuan penelitian ini menunjukkan hasil bahwa terdapat hubungan positif yang sangat signifikan antara grit dengan penyesuaian diri. Artinya, semakin tinggi grit yang dimiliki siswa semakin tinggi juga penyesuaian diri yang dimiliki oleh siswa boarding school. Maka penting bagi pendidik untuk dapat membantu siswanya mengembangkan grit. Namun, pendidik juga perlu memahami adanya faktor-faktor lain yang berpengaruh terhadap penyesuaian diri siswa, hal itu dapat dipertimbangkan oleh pengelola asrama untuk terwujudnya lingkungan asrama yang harmonis.

\section{Daftar Pustaka}

[1] Virtanen T. E., Vasalampi K., Torppa M., Lerkkanen M.-K., \& Nurmi J.-E. (2019). Changes in students' psychological well-being during transition from primary school to lower secondary school: a person-centered approach. Learning and Individual Difference. 69, 138-149.

[2] Purwanto. (2011). Evaluasi hasil belajar. Yogyakarta: Pustaka Pelajar.

[3] Dimyati, D. (2015, 13 November). Problem dan solusi pendidikan di sekolah berasrama. http://almasoem.sch.id/pesantren/problem-dan-solusipendidikansekolah-berasrama-boardingschool.

[4] Rodríguez-Fernández, A., Droguett, L., \& Revuelta, L. (2012). School and personal adjustment in adolescence: The role of academic self-concept and perceived social support. Revista de Psicodidáctica, 17(2), 397-415.

[5] Desmita. (2010). Psikologi perkembangan peserta didik. Bandung: Remaja Rosdakarya. 
[6] Marengo D., Jungert T., Iotti N. O., Settanni M., Thornberg R., Longobardi C. (2018). Conflictual student-teacher relationship, emotional and behavioral problems, prosocial behavior, and their associations with bullies, victims, and bullies/victims. Education Psychology. 38, 1201-1217.

[7] Sawhney, N \& Kaur, H. (2016). Study of emotional intelligence in relation to adjustment of secondary school students. Indian Journal of Educational Studies: An Interdisciplinary Journal, $3(1), 90-96$.

[8] Krish, S.J., Duffy, K.G., \& Atwater, E. (2013). Psycology for living: Adjustment, growth, and behavior today (11 th Ed)._New Jersey: Pearson Prentice.

[9] Moritsugu, J., Vera, E.M., Jacobs, J.H., \& Kennedy, M. (2016). Psychology adjustment: the search for meaningful balance. California: SAGE Publications, Inc

[10] Duckworth, A. L., Peterson, C., Matthews, M. D., \& Kelly, D. R. (2007). Grit: perseverance and passion for long-term goals. Journal of Personality and Social Psychology, 92(6), 1087-1101

[11] MacCann, C., \& Roberts, R. D. (2010). Do time management, grit, and self-control relate to academic achievement independently of conscientiousness?. Queensland: Australian Academic Press

[12] Credé, M., Tynan, M.C., \& Harms, P.D. (2016). Much ado about grit: a meta-analytic synthesis of the grit literature. Journal of Personality And Social Psychology. 113(3), 492-511

[13] Thaler, L. K., \& Koval, R. (2015). Grit to great: How perseverance, passion, and pluck take you from ordinary to extraordinary. New York: Crown Business.

[14] Duckworth, A.L. (2007). Grit: The power of passion and perseverance. New York: Scribner.

[15] Credé, M., \& Niehorster, S. (2012). Adjustment to college as measured by the student adaptation to college questionnaire: A quantitative review of its structure and relationships with correlates and consequences. Educational Psychology Review, 24(1), 133-165.

[16] Eskreis-Winkler, L., Shulman, E. P., Beal, S. A., \& Duckworth, A. L. (2014). The grit effect: predicting retention in the military, the workplace, school and marriage. Frontiers in Psychology, $5(36)$.

[17] Lee, S. J., \& Park, J. Y. (2018). The effects of grit and stress on nursing student's adjustment to college life. Journal of Digital Convergence, 16(2), 269-276.

[18] Sudarji, S., \& Juniarti, F. (2020). Perbedaan grit pada mahasiswa perantau dan bukan perantau di universitas "x". Psyche: Jurnal Psikologi, 2(1), 1-10.

[19] Datu, J. A. D., Valdez, J. P. M., \& King, R. B. (2016). Perseverance counts but consistency does not! Validating the short grit scale in a collectivist setting. Current Psychology, 35(1), 121-130.

[20] Tovar-García, E. D. (2017). The impact of perseverance and passion for long term goals (GRIT) on educational achievements of migrant children: Evidence from Tatarstan, Russia. Psicologia Educativa, 23(1), 19-27. 